DOI https://doi.org/10.32837/app.v63i0.6

УДК 316.77+007

Каретна О. О. ${ }^{*}($ НУ «ОЮА»)

\title{
ТЕОРЕТИЧНИЙ АНАЛІЗ ІНТЕРАКЦІЇ ВЛАДИ І ГРОМАДЯНСЬКОГО СУСПІЛЬСТВА ТА ЇХ ПРОЯВИ В УКРАЇНСЬКОМУ СУСПІЛЬСТВІ
}

\section{THEORETICAL ANALYSIS OF THE INTERACTION BETWEEN THE POWER AND THE CIVIL SOCIETY AND THEIR MANIFESTATIONS IN UKRAINIAN SOCIETY}

*Olga Karetna - PhD in Political Science, Associate professor, Department of Sociology and Psychology, National University "Odesa Law Academy" (23, Fontanska Doroha St., Odesa, Ukraine).

\section{Abstract}

In modern conditions of power reforms in Ukraine, the communication between power and society is an important tool for the planned changes; the process of decentralization of power is the system of distribution of functions and powers between state and local levels of government to expand the rights of the latter. One of the risks of the decentralization process is the lack of awareness among participants and members of society. The lack of sufficient, reliable information can exacerbate social conflicts.

Effective interaction can be achieved if the communication will be considered by the authorities as an integral part of the management process. In order to achieve a more efficient process of interaction with the public, the authorities can use in their work social networks, webinars, and other means of Internet communications.

Today, the Internet provides ample opportunities for the use of various content, a relaxed style of communication - all this will allow attracting more people to interact with authorities, to increase the level of transparency of such interaction and the level of trust in authorities.

Citizen participation in public authority is a manifestation of public control over the activities of government representatives. The most effective forms of public 
participation in the process of interaction between the authorities and the public are the provision of information, counseling, dialogue and active participation.

Keywords: society, power, communications, civil society.

Актуальність даної проблеми обумовлена умовами політичних змін, а так само здійсненням системного реформування сфер суспільного життя в суспільстві, в нинішніх умовах розвитку суспільства об'єктивно зростає потреба громадян в значній інформованості про цілі, плани та дії влади. Важливе значення в даному випадку набуває готовність органів державної влади і місцевого самоврядування використовувати ефективні механізми взаємодії з громадськістю, як безпосередньо (із залученням громадських організацій), так і опосередковано (через електронні засоби).

Постановка проблеми необхідність комплексного аналізу комунікативої взаємодії влади та громадськості, що охоплює різні етапи ухвалення державно-владних рішень, форми співпраці та контрольних повноважень.

Мета дослідження полягає у аналізі моделі ефективної комунікації між владою та суспільством.

Аналіз основних досліджень та публікацій. Дослідженню проблем комунікацій та інформаційно-комунікаційних технологій в сфері державного управління присвячені роботи багатьох вітчизняних та зарубіжних вчених, наприклад Ю. Габермас, Г. Почепщов, О. Дніпров, А. Сунгурова, Ю. Горбань., Н. Лісова, А. Халецький, і т.д.

Ефективність державного управління багато в чому залежить від рівня налагодження комунікації між різними органами державної влади, громадськими групами і засобами масової інформації. На думку професора Почепцова Г.Г., саме комунікації є формою існування влади.

Влада не тільки повинна брати участь в комунікаціях 3 населенням, вона так само повинна сама бути ініціатором нових типів комунікації. Вчений пропонує наступні типи комунікації: «влада населення» і «населення - населення» і розділяє їх відносно «влада - населення» (10\%): «населення - населення» (90\%). Найчастіше комунікація «влада - населення» виникає в кризових ситуаціях і виконує такі функції як: корекції висвітлення події в інформаційному просторі, підготовку до майбутньої події, утримання уваги після закінчення події, перемикання уваги. Увага до комунікації в системі «населення - населення» 3'явилася не так давно. Коли в уряді 
Т. Блера за це відповідав один чоловік, в уряді Д. Камерона цим займається ціла команда (Горбань, 2013, с. 40).

Сьогодні в Україні проводиться ряд реформ, які повинні кардинально змінити суспільне життя в державі і прискорити подальший розвиток країни у всебічному ії розвитку. Це все передбачає істотну зміну режиму комунікації між органами влади, з громадянами зокрема, і з громадянським суспільством в цілому.

Згідно з дослідженнями, які надають вчені, взаємодія між органами влади та громадськістю виникає та реалізується в різних площинах і тут існують різні варіанти: по-перше, це стосується взаємних потреб, прагнень, інтересів, мотивації; по-друге, нормативно-правової бази взаємодії; по-третє, ресурсної бази взаємодії (включає в себе як матеріальні, так і нематеріальні ресурси учасників співробітництва), по-четверте це економічна база взаємодії (включаючи не тільки матеріальні ресурси, і їх облік, а й інші фінансові ресурси), і по-п'яте це комунікативна (інформаційна) база взаємодії (включає процедури та механізми діалогу між партнерами) (Лісова, 2016, с. 185).

Для вирішення даної проблеми необхідно вводити нові комунікативні технології управління, які здатні були б відновлювати довіру до органів влади та різним громадським організаціям.

Як показує практика, державно-громадське управління не може існувати без комунікації, оскільки демократичний принцип вимагає постійного діалогу між органами влади, органами самоврядування та громадськістю. Головна мета комунікації це створення довірчих відносин між сторонами-партнерами, забезпечення очікувань з боку громадськості та налагодження партнерських відносин між ними (Лісова, 2016, с. 187).

У загальному вигляді проблема налагодження системного і ефективного діалогу між владою і громадянами констатується багатьма авторами.

У сфері владної діяльності, на думку А.С. Дніпровській, можливості налагодження діалогу потрібно досліджувати структурно. В Україні вимагають активізації такі аспекти як діалог громадськості та влади під цими аспектами ми розуміємо наступне:

- це настройка комунікації шляхом удосконалення функціонування органів державної влади. Закріплення і поліпшення реалізації принципів відкритості, доступності, прозорості, демократії та гласності, що і є вагомими критеріями діяльності органів виконавчої влади; 
- діалог відбувається шляхом забезпечення можливості громадянам брати участь в управлінні державними справами.

- діалог відбувається шляхом використання новітніх інформаційних технологій, тобто впровадження в управлінську діяльність модернових тенденцій розвитку комунікативних технологій.

- комунікативна діяльність органів державної виконавчої влади.

- подолання корумпованості чиновницького апарату призводить до девіаційних проявів у владі (Дніпров, 2015, с. 29).

Масштабування та характер поширення участі демократії залежить від того, як функціонує система «держава - громадянське суспільство», оскільки тільки останній здатен сформувати орієнтації на використання громадянами діалогових форм політичної участі. Можна говорити про чотири основні варіанти діалогу між владою і громадянами.

Перший передбачає використання владою традиційної стратегії взаємодії з громадянами зверху - вниз, заснована на наданні останнім мінімуму інформації про хід процесу прийняття політичних рішень і повністю заперечує їх суб'єктність в процесі формування політичного порядку. Фактично цей тип діалогу є монологом влади, що претендує виключно на позитивну оцінку з боку громадян. Другий варіант діалогу - взаємодія, обмежена зверху - є стратегією обмеженого діалогу, коли влада погоджується приймати пропозиції від громадян, проте не поспішає, реагувати на дані пропозиції.

Третій варіант передбачає відкритий діалог між владою і громадянами, однак остаточний вибір пріоритетів залишається за владою, оскільки вона вибирає стратегію взаємодії з громадянами за принципом «так... але...».

Четвертий варіант діалогу, який відповідає принципам функціонування демократії участі, формується на основі спільного володіння інформацією, тому рядові громадяни є рівними з владою суб'єктами політичного процесу, а їх пропозиції мають таке ж значення, як і пропозиції влади. Тут слід звернути увагу, що тільки останній варіант діалогу між владою і громадянами передбачає рівні права контролю над реалізацією спільно прийнятих політичних рішень. Останній варіант діалогу в українській політичній практиці більш відомий в термінах стратегії партнерства між владою та громадянським суспільством (Ротар, 2007, с. 78).

Одним з найважливіших аспектів процесу комунікації між владою та громадянами, повинен сприяти формуванню діалогових форм 
політичної участі, це повинно в свою чергу забезпечити оптимізацію доступу громадян до інформації про діяльність органів центральної і місцевої влади. Тут варто звернути увагу, що володіння якісної інформації визначає характер політичної компетентності громадян, iï рівень, інструментальні та функціональні характеристики.

Відповідно до Закону України «Про інформацію» (ст. 10), обов'язком органів державної влади, органів місцевого і регіонального самоврядування $є$ інформування про свою діяльність і прийняті рішення; створення в державних органах влади спеціальних інформаційних служб та систем, забезпечувати доступ громадян до інформації в установленому порядку; забезпечення вільного доступу суб'єктів інформаційних відносин до статистичних даних, архівних, бібліотечних і музейних фондів (Закон про інформацію від 02.10.1992 № 2658-XII)

Під ефективною комунікацією ми розуміємо взаємодію яка передбачає зворотний зв'язок і дозволяє підтримувати інтерес та довіру населення до діяльності влади. Як відзначають експерти, важливість формування ефективної комунікації доцільна з наступних причин: ефективна комунікація між владою і населенням сприяє вирішенню проблем громадян шляхом донесення їх влади; вирішуючи проблеми громадян, влада формує про свою діяльність позитивну думку, тим самим сприяє підвищенню рівня довіри та мінімізує можливі протести з боку суспільства; висвітлюючи таку діяльність, 3МІ підвищують свій рейтинг, шляхом підвищення кількості переглядів реальними людьми і подіями, учасники яких цікавляться даними сюжетами (Корж, 2017,с. 17).

Ефективна взаємодія органів державної влади з громадянським суспільством можливо при наявності наступних умов:

- комунікація розглядається органами державної влади як невід'ємна складова їх діяльності;

- в структурі органів державної влади є відповідні підрозділи, які вирішують завдання контролювати інформаційні та комунікативні потоки і відповідним чином їх направляти;

- фахівці таких підрозділів повинні бути підготовлені, і є менеджерами комунікації органів влади, а не їх комунікаторами (Юрченко, 2012).

На думку дослідника Ю. Воробйова, необхідно класифікувати моделі комунікативної політики, незважаючи на рівень управління: державна влада - громадянське суспільство та муніципальна влада - 
суспільство. Особливу роль автор приділяє так званої концептуальної моделі комунікативної взаємодії на рівні «державна влада - громадянське суспільство», яка має трирівневий ефект: довгостроковий (стратегічний ефект), середньостроковий (накопичувальний ефект) і короткостроковий (разовий ефект), кожен з яких характеризується певними формами взаємодії, діалогічності та договірного партнерства органів державної влади з громадськістю. У своїй сукупності ці форми взаємодії забезпечують взаємний контроль і рівновагу інтересів в системі відносин «державна влада - громадянське суспільство» (Романенко, 2014).

Варто виділити комунікативні стратегії, які впливають на формування рівня довіри громадськості до діяльності органів державної влади в суспільстві. Виходячи із зазначеного, вбачається існування трьох структурних моделей комунікації, які:

- вчать громадськість брати участь в процесах формування та реалізації державної політики;

- встановлюють невідповідність державної політики, інтересам громадськості, спонукаючи останню до участі у формуванні та реалізації (оптимізує їі роль у формуванні та реалізації державного управління);

- визначають рівень включення громадськості в процеси формування і реалізації державної політики (недостатній рівень інформованості громадян про зміст державної політики, або навіть неадекватне iї розуміння) (Шклярук, 2018, с. 4).

В рамках комунікативних досліджень на особливу увагу заслуговує також підхід А. Сунгурова, який виділив сім моделей комунікативної політики, що характеризують взаємодію органів державної влади та громадянського суспільства, в тому числі:

- модель підтримки розвитку інститутів громадянського суспільства, передбачає прийняття відповідної нормативно-правової бази, що забезпечує розвиток інститутів громадянського суспільства;

- партнерська модель, передбачає паритетну взаємодію органів державної влади та громадськості, при якій вони уникають будь-яких форм управління суспільством, співпрацюючи з ним у формі діалогу, створюючи для цього так звані «переговорні майданчики»;

- модель архітектора, передбачає активну роль громадськості в створенні нових інституційних структур органів державної влади;

- патерналістська модель забезпечує певну автономію громадських організацій за винятком підтримки певних політичних сил чи 
окремих кандидатів у відповідному виборчому процесі, надаючи їм певну інституційну та фінансову підтримку;

- модель привідних ременів, характеризує домінування інтересів над інтересами громадянського суспільства;

- модель ігнорування, яка стає можливою за умови відсутності будь-яких форм взаємодії органів державної влади і громадськості в суспільстві;

- моделі боротьби з противником і громадянської непокори, характеризує певні конфронтаційні відносини в рамках суспільства, коли органи державної влади вдаються до тотального контролю за діяльністю інститутів громадянського суспільства, побачивши в них головну небезпеку для своєї діяльності; у відповідь на це громадяни змушені вдаватися до відповідних протестних дій (мітинги, пікети, протести) (Романенко, 2014, с. 2).

Основним критерієм ефективності функціонування відносин влади з громадськістю є створення умов для вільного прийняття громадянами дій органів влади, прийнятих ними рішень. Тому саме в формі двостороннього, збалансованого зв' язку суспільства і влади створюються найбільш оптимальні умови для ефективного функціонування суб'єктів зазначених відносин оскільки передбачає: - відкритість інформаційних потоків в поясненні змісту державної політики, що гарантує максимальну свободу в обговоренні громадських проблем;

- сприяння розумінню громадянами діяльності органів державної влади, доцільності прийняття ними відповідних рішень;

- активна участь громадськості в управлінні державою, супроводжується систематичним залученням її до вирішення соціально значущих проблем;

- організацію і підтримку владою соціальних дискусій шляхом залучення громадськості до процесів створення та реалізації державної політики (Корж, 2017, с. 19).

Реалізація перерахованих вище дій підвищує інтерес до потенціалу нових форм державного управління, введених в демократичних країнах, сприяє оновленню суспільних відносин під впливом орієнтації на діалог, свободу і активну участь громадськості в державному управлінні, демократизації соціальних інститутів, налагодження діалогових форм співпраці влади та громадськості України.

У роботі з громадськістю потрібно підбирати ті методи і форми роботи, які прийнятні для нас, а також для партнерів з громадського діалогу. 
Ю. Коваль пропонує до комунікативним критеріїв ефективності влади ввести поняття Ю. Габермаса «взаєморозуміння». Значення названої категорії полягає в тому, що воно виступає багатозначним аспектом визнання сфер «життєвого світу» $\mathrm{i}$ «системи» певних меж як втручання, так і взаємодії, відповідно розуміння Ю. Габермаса, має здійснюватися за такими принципами:

- «зрозумілість» повідомлень влади (в даному випадку мається на увазі те, що сама влада повинна стати ініціатором «соціального діалогу» 3 громадськістю, запропонувати певні вектори розвитку соціуму без напливів на вплив держави на приватну сферу);

- «істинність» знання (мається на увазі компетентність влади у вирішенні, гострих соціальних питань,);

- «правдивість» намірів (тут ми повинні розуміти орієнтацію влади на суворе дотримання декларованої політики чи передвиборчим обіцянкам, а саме на цьому рівні, влада повинна пояснювати населенню причини і межі коригування декларативного рівня зрозумілим для громадян аргументом);

- «правильність» дій (на думку Ю. Габермаса це певний рівень дискурсивної політики, тобто не змісту дії влади, а реакції соціуму та вмісту повідомлення). Недолік тут полягає в тому, що розуміння комунікації влади та населення тільки за вербальними і невербальними засобами спілкування дуже шкідлива для політики (Коваль, 2014, с. 59).

Ю. Габермас пропонує наступну концепцію поділу влади: влада яка народжується в процесі вільних, необмежених комунікативних дій політичної громадськості в рамках «життєвого світу», і адміністративну владу в руках «системного світу». Для «життєвого світу» характерна децентралізація, спонтанність протікання соціальних процесів, здатність до обмеження адміністративного апарату, інституціоналізація громадської думки, активну участь громадян у розробці та прийняті політичних рішень (Коваль, 2014, с. 60).

Можливість вести комунікацію $з$ представниками влади не тільки у виборчий період, а й постійно підтримувати зв' язок з ними он-лайн або безпосередньо, спонукає громадян формувати свої позиції та робити оцінки на основі інформації, отриманої з ЗМІ та інших джерел. Це перетворює їх в активних акторів вироблення політики та змушує шукати нові канали впливу на законотворчий процес.

Український парламент зробив крок назустріч суспільству, запровадивши в дію портал громадського обговорення законопроектів, 
розроблений за підтримкою Програми USAID РАДА та з ініціативи Управління комп'ютерних систем апарату ВРУ у відповідь на рекомендації Європейського Парламенту по внутрішньому реформуванню Верховної Ради з метою поліпшення її інституційної спроможності.

Зазначене дає можливість громадянам заздалегідь ознайомитися з законопроектами, які повинні бути внесені на обговорення парламенту, і знаходяться на розгляді профільних комітетів, та брати участь в їх обговоренні. Крім того, вказане дозволяє поліпшити прозорість діяльності та довіру до комітетів, а це є частиною комплексної програми відкритості комітетів (Корж, 2017, с. 22).

Однією з проблем, яка заважає налагодженню ефективної роботи органів виконавчої влади з громадськістю, по-перше це відсутність відповідної професійної підготовки багатьох державних службовців 3 питань використання інтернет - технологій при формуванні комунікаційних зв' язків з громадськістю, по-друге проблемне питання в роботі підрозділів з питань взаємодії із засобами масової інформації та зв'язків з громадськістю - їх постійна реорганізація, яка не $\epsilon$ результатом ні системного бачення функцій організації і структури в цілому, ні певної стратегії. В таких умовах найбільш поширеними методами стратегічної комунікації сьогодні залишаються проведення прес-конференцій, семінарів, тренінгів, консультацій; надання інформації окремому журналісту; поширення прес-релізів; випуск брошур, буклетів, плакатів, бюлетенів (друкованих та електронних) розміщення інформації на сайті, біг-бордах; реклама, підготовка теле- та радіороликів тощо.

Почати освоєння інтернет-технологій органами державного управління можна з простого і недорогого інструменту - 3 вебінарів, веб-конференцій у віртуальних кабінетах, організованих за допомогою спеціалізованих веб-сервісів, яким є і сайт (Халецький 2012).

Таким чином, в Україні вже створені певні передумови (правові, організаційні і т.д.) для підвищення ефективності комунікацій державних органів з громадськістю, які забезпечують становлення та розвиток партнерства влади і суспільства. Впровадження і використання віртуальних технологій в сфері державного управління, а саме, при організації взаємодії органів державної влади з громадськістю, треба констатувати, що веб-технології дозволять ефективно проводити комунікаційну політику державного органу, оптимізуючи комунікативний процес, заощаджуючи робочий час і даючи можливість більш оперативно обмінюватися інформацією. 


\section{Лiтература:}

Горбань Ю. О. (2013). Новітні комунікативні можливості у взаємодії 3MI, органів державної влади та громадських організацій. Вісник НАДУ, 4, 38-46.

Дніпров О. С. (2015). Діалог органів державної виконавчої влади та громадянського суспільства. Вісник Національного університету «Львівська політехніка», 825, 26-30.

Закон про інформацію від 02.10.1992 № 2658-XII (Верховна Рада України). Відомості Верховної Ради України, 48, 651. <https:/ / zakon.rada.gov.ua/ laws/show/2657-12/ed20110106>.

Коваль Ю. О. (2014). Комунікативний підхід Юргена Габермаса як критерій ефективності державної влади. Вісник СевНТУ: зб. наук. пр. Севастополь, Вип. 145/2014, 58-62.

Корж І. Ф. (2017). Комунікація влади і суспільства в умовах децентралізації. Інформація і право, 1 (20), 14-27.

Лісова Н. (2016). Соціальне партнерство як основа державногромадського управління загальною середньою освітою. Психологопедагогічні проблеми сільської школи, Вип. 54, 183-191.

Романенко Є. О. (2014). Моделі комунікативної політики держави та інструментальне забезпечення взаємодії органів державної влади та громадськості. Демократичне врядування, Вип. 14. <http:/ / lvivacademy. com/vidavnitstvo_1/visnyk14/fail/romanenko.pdf>.

Ротар Н. (2007). Діалогові форми політичної участі: передумови та перспективи становлення в Україні. Політичний менеджмент, 1, 75-92.

Халецький А. В. (2012). Державна комунікативна політика як інструмент ефективної розбудови громадянського суспільства в умовах суспільноекономічних трансформацій. Державне управління: удосконалення та розвиток, 10. <http://nbuv.gov.ua/UJRN/Duur_2012_10_12>.

Шклярук М. Г. (2018). Структура стратегічних комунікацій у системі демократичного державного управління. Державне управління: удосконалення та розвиток, 1. <http://www.dy.nayka.com.ua/ pdf/1_2018/103.pdf>.

Юрченко В. Е. (2012). Комунікативні технології як механізми взаємодії громадянського суспільства та державної влади. Державне будівництво, 1 . <http://www.kbuapa.kharkov.ua/e-book/db/2012-1/doc/4/06.pdf>. 


\section{References:}

Dniprov O. S. (2015). Dialog organiv derzhavnoyi vy`konavchoyi vlady` ta gromadyans `kogo suspil`stva [Dialogue between state executive bodies and civil society]. Visny 'k Nacional nogo universy tetu «L'vivs 'ka politexnika» [Bulletin of the National University of Lviv Polytechnic], 825, 26-30. [in Ukrainian].

Gorban`Yu. O. (2013). Novitni komunikaty`vni mozhly`vosti u vzayemodiyi ZMI, organiv derzhavnoyi vlady` ta gromads `ky`x organizacij [New communication opportunities in the interaction of mass media, state authorities and public organizations]. Visny $k$ NADU [NADU Bulletin], 4, 38-46. [in Ukrainian].

Korzh I. F. (2017). Komunikaciya vlady`i suspil`stva v umovax decentralizaciyi [Communication between government and society in the context of decentralization]. Informaciya $i$ pravo [Information and Law], 1 (20), 14-27. [in Ukrainian].

Koval` Yu. O. (2014). Komunikaty`vny`j pidxid Yurgena Gabermasa yak kry`terij efekty`vnosti derzhavnoyi vlady` [Jurgen Habermas's Communicative Approach as a Criterion for State Power Efficiency]. Visny `k SevNTU: zb. nauk. pr. [SevNTU Bulletin: Coll. Sciences], Sevastopol', Vy`p. 145/2014, 58-62. [in Ukrainian].

Lisova N. (2016). Social`ne partnerstvo yak osnova derzhavno-gromads`kogo upravlinnya zagal`noyu seredn`oyu osvitoyu [Social partnership as a basis for public-public management of general secondary education]. Psy'xologopedagogichni problemy' sil's 'koyi shkoly' [Psychological and pedagogical problems of a rural school], Vy`p. 54, 183-191. [in Ukrainian].

Romanenko Ye. O. (2014). Modeli komunikaty`vnoyi polity`ky`derzhavy` ta instrumental'ne zabezpechennya vzayemodiyi organiv derzhavnoyi vlady` ta gromads`kosti [Models of communication policy of the state and instrumental support of interaction between public authorities and the public]. Demokraty chne vryaduvannya [Democratic Governance], Vy`p. 14. <http://lvivacademy.com/vidavnitstvo_1/visnyk14/fail/romanenko. pdf $>$. [in Ukrainian].

Rotar N. (2007). Dialogovi formy` polity`chnoyi uchasti: peredumovy` ta perspekty`vy' stanovlennya v Ukrayini [Dialogue Forms of Political Participation: Prerequisites and Prospects for Becoming in Ukraine]. Polity 'chny j menedzhment [Political Management], 1, 75-92. [in Ukrainian]. Shklyaruk M. G. (2018). Struktura strategichny`x komunikacij u sy`stemi demokraty`chnogo derzhavnogo upravlinnya [Structure of strategic 
communications in the system of democratic public administration]. Derzhavne upravlinnya: udoskonalennya ta rozvy tok [Public Administration: Improvement and Development], 1. <http://www.dy.nayka.com.ua/ pdf/1_2018/103.pdf>. [in Ukrainian].

Xalecz`ky`j A. V. (2012). Derzhavna komunikaty`vna polity`ka yak instrument efekty`vnoyi rozbudovy` gromadyans`kogo suspil`stva v umovax suspil`noekonomichny` $x$ transformacij [State communication policy as an instrument of effective civil society development in the conditions of socio-economic transformations]. Derzhavne upravlinnya: udoskonalennya ta rozvy tok [Public Administration: Improvement and Development], 10. <http://nbuv.gov. ua/UJRN/Duur_2012_10_12>. [in Ukrainian].

Yurchenko V. E. (2012). Komunikaty`vni texnologiyi yak mexanizmy` vzayemodiyi gromadyans`kogo suspil`stva ta derzhavnoyi vlady` [Communication technologies as mechanisms of interaction between civil society and state power]. Derzhavne budivny 'cztvo [State Building], 1. <http://www.kbuapa.kharkov.ua/e-book/db/2012-1/doc/4/06.pdf>. [in Ukrainian].

Zakon pro informaciyu vid 02.10.1992 \# 2658-XII (Verxovna Rada Ukrayiny`) [Zakon pro informaciyu vid 02.10.1992 \# 2658-XII (Verxovna Rada Ukrayiny')]. Vidomosti Verxovnoyi Rady Ukrayiny' [Vidomosti Verxovnoyi Rady`Ukrayiny`], 48, 651. <https://zakon.rada.gov.ua/laws/ show/2657-12/ed20110106>. [in Ukrainian].

\section{Анотація}

Каретна О. О. Теоретичний аналіз інтеракиї̈ Влади і громадянського суспільства та їх прояви в українському суспільстві. -

\section{Стаття.}

Створення єдиного інформаційно-комунікаційного простору Украйни як частини світового інформаиійного простору є одним з умов побудови демократичного суспільства. Інформаційно-комунікаційні процеси забезпечить рівноправну участь украӥнського суспільства $b$ процесах інфрормаційної $i$ економічної інтеграції з іншими країнами і народами. Основною проблемою на шляху демократизації участь громадськості у формуванні та реалізації політичного курсу, виступає саме тим соціально-правовим інститутом, в якому концентрується найбільший потенціал до діалогу влади та суспільства

Ключові слова: суспільство, влада, комунікації, громадянське суспільcmbo. 